\title{
Differentiation of the bovine dominant follicle from the cohort upregulates mRNA expression for new tissue development genes
}

\author{
M Mihm, P J Baker, L M Fleming, A M Monteiro and P J O'Shaughnessy \\ Division of Cell Sciences, Faculty of Veterinary Medicine, University of Glasgow, Bearsden Road, Glasgow G61 1QH, UK \\ Correspondence should be addressed to M Mihm; Email: m.mihm@vet.gla.ac.uk
}

\begin{abstract}
This study was designed to identify genes that regulate the transition from FSH- to LH-dependent development in the bovine dominant follicle (DF). Serial analysis of gene expression (SAGE) was used to compare the transcriptome of granulosa cells isolated from the most oestrogenic growing cohort follicle (COH), the newly selected DF and its largest subordinate follicle (SF) which is destined for atresia. Follicle diameter, follicular fluid oestradiol (E) and E:progesterone ratio confirmed follicle identity. Results show that there are 93 transcript species differentially expressed in DF granulosa cells, but only 8 of these encode proteins known to be involved in DF development. Most characterised transcripts upregulated in the DF are from tissue development genes that regulate cell differentiation, proliferation, apoptosis, signalling and tissue remodelling. Semiquantitative real-time PCR analysis confirmed seven genes with upregulated $(\boldsymbol{P} \leq \mathbf{0 . 0 5})$ mRNA expression in DF compared with both $\mathrm{COH}$ and SF granulosa cells. Thus, the new genes identified by SAGE and real-time PCR, which show enhanced mRNA expression in the DF, may regulate proliferation (cyclin D2; CCND2), prevention of apoptosis or DNA damage (growth arrest and DNA damage-inducible, $\beta$; GADD45B), RNA synthesis (splicing factor, arginine/serine rich 9; SFRS9) and unknown processes associated with enhanced steroidogenesis (ovary-specific acidic protein; DQ004742) in granulosa cells of DF at the onset of LH-dependent development. Further studies are required to show whether the expression of identified genes is dysregulated when abnormalities occur during DF selection or subsequent development.
\end{abstract}

Reproduction (2008) 135 253-265

\section{Introduction}

In females from single-ovulating species, such as cattle and humans, the final stages of antral follicle development begin with (1) stimulation of cohort growth through a transient rise in serum follicle-stimulating hormone (FSH) concentrations, (2) subsequent atresia of an increasing number of cohort follicles during declining FSH and (3) identification ('selection') of a single dominant follicle (DF) which alone continues development despite FSH concentrations reaching nadir levels (Adams et al. 1993, Sunderland et al. 1994, van Santbrink et al. 1995, Baerwald et al. 2003). Cohort follicles, therefore, require elevated concentrations of FSH (FSH 'dependent'), while the DF, in contrast, develops relative $\mathrm{FSH}$ 'independence' demonstrated by its enhanced growth and oestradiol (E) synthesis in a low $\mathrm{FSH}$ environment. However, the DF now requires frequent stimulation by luteinizing hormone (LH) to continue differentiation leading up to ovulation ( $\mathrm{LH}-$ 'dependent' stage of development; Mihm \& Bleach 2003). Understanding the cellular mechanisms that permit the transit from the $\mathrm{FSH}$ - to the $\mathrm{LH}$-dependent developmental stage in the DF is imperative, as abnormalities in follicle selection and/or subsequent final differentiation result in anovulation, and are thus main causes of ovarian infertility in cattle and women (Lucy 2001, Evers 2002).

Previous studies have used the bovine DF model to examine changes in the expression of known follicular genes (such as for $\mathrm{FSH}$ and $\mathrm{LH}$ receptors, steroidogenic enzymes, specific growth factors and their binding proteins) when the DF becomes selected from the cohort (Bao \& Garverick 1998, Yuan et al. 1998, Canty et al. 2006). While this candidate gene approach has merit, it is clear that approaches that utilise global gene and protein expression profiling are required to identify all key factors and pathways which regulate cell differentiation during DF development. Genomic approaches so far used (suppression subtractive hybridisation, custom cDNA microarray) have focussed on the comparison between the highly oestrogenic selected DF at the beginning of the rapid growth phase with subordinate follicles undergoing or initiating atresia (Sisco et al. 2003, Evans et al. 2004, Fayad et al. 2004). Such comparisons have identified genes that regulate $\mathrm{E}$ synthesis or apoptosis within the growing cohort (Sisco et al. 2003) for example. However, a global transcription profiling approach has not been applied to determine changes that occur in granulosa cells when the most successful cohort follicle becomes the DF. 
To address this important step of DF differentiation, our aim was to identify the changes in the granulosa cell transcriptome, which occur as the DF transits from the FSH- to the LH-dependent development stage, enhancing its growth and $\mathrm{E}$ synthesis and, at the same time, preventing the onset of atresia. As a consequence, we have used serial analysis of gene expression (SAGE), a comprehensive, unbiased and quantitative gene expression profiling technique to generate and then compare the transcriptome of bovine granulosa cells from the DF before its selection $(\mathrm{COH})$, the DF at the onset of dominance and its largest subordinate follicle fated to undergo atresia (SF).

\section{Results \\ DF model}

Frequent ovarian ultrasound scanning was used in dairy cows to monitor development of antral follicles belonging to the first cohort of the cycle until recovery of the largest, most oestrogenic cohort follicle $(\mathrm{COH})$ before the DF can be identified (4 cows), and of the DF and SF at or just after the time when their divergence in growth was determined (4 cows). All follicles were growing at the time of recovery, which was 1.3 days earlier $(P<0.05)$ for the $\mathrm{COH}$ than for the DF and SF (Fig. 1; Table 1). Ultrasound analysis showed $<1 \mathrm{~mm}$ difference in diameter between the $\mathrm{COH}$ and the other growing cohort members (Fig. 1). Following dissection, the $\mathrm{COH}$ were the smallest with the lowest intrafollicular $E$ compared with both the DF and SF $(P<0.05$, Table 1$)$. All follicles were oestrogenic (oestradiol:progesterone (E:P) ratio in follicular fluid $>1$, Ireland \& Roche 1983), but the DF showed a sevenfold increase in the E:P ratio from the $\mathrm{COH}(P<0.05)$, and was larger and had higher intrafollicular $E$ leading to a threefold higher $E: P$ ratio than the SF $(P<0.05$; Table 1$)$. Thus, the DF and SF were recovered at the onset of dominance in the DF (three cows) or $12 \mathrm{~h}$ after (one cow) based on morphological and hormonal criteria (Fig. 1; Table 1; Mihm et al. 1997, Austin et al. 2001).

\section{SAGE analysis of differentially expressed transcripts in the DF granulosa cells}

Generation of SAGE libraries involved the sequencing of 14-nucleotide SAGE tags, each of which represents one transcript species. All tags that were differentially expressed $(P \leq 0.05)$ in the DF compared with both the $\mathrm{COH}$ and SF granulosa cell libraries are shown in Table 2. Only 8 out of the 93 identified tags matched genes previously associated with bovine DF development (descriptions below). The overwhelming majority of genes regulated in the DF have not previously been associated with ovarian function. Functional analysis of the transcripts listed in Table 2 is shown in Fig. 2A-D. The largest proportion of characterised transcripts

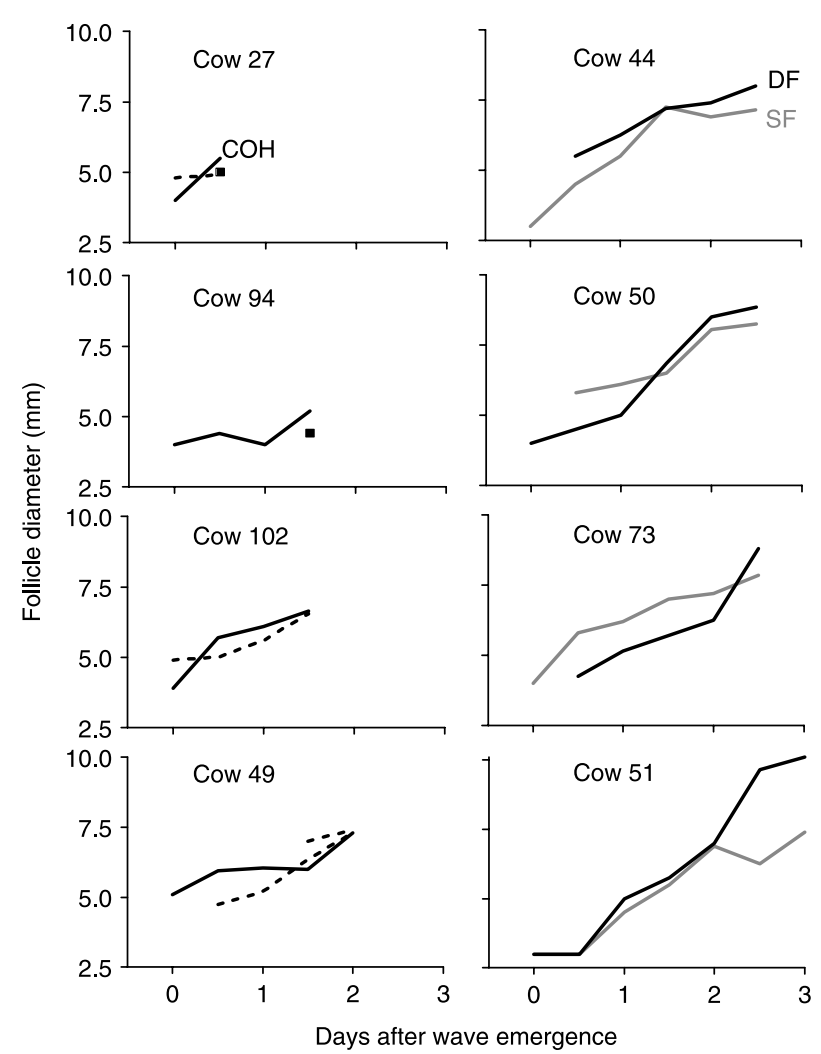

Figure 1 Growth of the most oestrogenic cohort (COH, black line), dominant (DF, black line) and the largest subordinate follicles (SF, grey line) in individual cows determined using ultrasound scanning from wave emergence to recovery of ovaries (mean \pm S.E.M. COH, DF and SF diameters measured at the last ultrasound examination before recovery were $6.2 \pm 0.5 \mathrm{~mm}, 8.9 \pm 0.4 \mathrm{~mm}$ and $7.7 \pm 0.2 \mathrm{~mm}$ respectively); the second and third (stippled lines) cohort follicle are included in the diagrams depicting $\mathrm{COH}$ growth to demonstrate that $\mathrm{COH}$ were recovered before a dominant follicle is selected (the square symbol is used once to depict a follicle only detected at the last ultrasound examination).

upregulated in the DF compared with both the $\mathrm{COH}$ and SF granulosa cell libraries matched tissue development genes that encompass genes regulating cell differentiation, proliferation, apoptosis, signalling and tissue remodelling (Fig. 2A). In contrast, no such transcripts were detected among those expressed at the highest levels in the SF compared with the DF (intermediate levels) and $\mathrm{COH}$ (lowest levels) libraries, while over $80 \%$ of transcripts matched genes regulating protein synthesis (Fig. 2D; $P<0.05$ ).

(A) Granulosa cell transcripts upregulated in the DF compared with both the $\mathrm{COH}$ and SF SAGE libraries (Table 2): SAGE analysis identified 17 characterised transcripts upregulated in the DF, which matched genes that either have not previously been associated with DF development (four tags) or have never been associated with ovarian function (13 tags). The cellular role of 1 (ovary-specific acidic protein; OSAP) out of the 17 genes is currently unknown, while the remaining 16 genes 
Table 1 Characteristics of first-wave follicles (means \pm s.E.M.) recovered from four cows before (COH) and four cows after (DF and SF) the onset of dominance.

\begin{tabular}{|c|c|c|c|}
\hline Follicle parameters & $\mathrm{COH}$ & DF & SF \\
\hline \multicolumn{4}{|l|}{ Time of follicle recovery } \\
\hline Interval from onset of oestrus (h) & $63 \pm 0.2^{\mathrm{a}}$ & $96.5 \pm 0.6^{\mathrm{b}}$ & \\
\hline Interval from cohort emergence (days) & $1.3 \pm 0.3^{\mathrm{a}}$ & $2.6 \pm 0.1^{\mathrm{b}}$ & \\
\hline Diameter after dissection $(\mathrm{mm})^{*}$ & $7.5 \pm 0.6^{\mathrm{a}}$ & $11.2 \pm 0.3^{\mathrm{b}}$ & $9.9 \pm 0.2^{\mathrm{c}}$ \\
\hline \multicolumn{4}{|c|}{ Follicular fluid hormone concentrations (ng/ml) } \\
\hline Oestradiol (E) & $26.3 \pm 5.0^{\mathrm{a}}$ & $319.8 \pm 136.5^{\mathrm{b}}$ & $79 \pm 13.3^{\mathrm{c}}$ \\
\hline Progesterone $(\mathrm{P})$ & $12.9 \pm 1.5^{\mathrm{a}}$ & $24.4 \pm 4.6^{\mathrm{b}}$ & $17.4 \pm 2.6^{\mathrm{a}, \mathrm{b}}$ \\
\hline $\mathrm{E}: \mathrm{P}$ ratio & $2.1 \pm 0.5^{\mathrm{a}}$ & $15.0 \pm 6.6^{\mathrm{b}}$ & $4.9 \pm 1.0^{\mathrm{C}}$ \\
\hline
\end{tabular}

${ }^{a, b, c}$ Different superscripts within rows indicate significant differences between follicle groups $(P<0.05)$.

${ }^{*}$ Measurements were available for only three $\mathrm{COH}$ for analysis.

have known functions in intracellular signalling (annexin A2 (ANXA2), calmodulin 2 (phosphorylase kinase, $\delta)$ (CALM2), chloride intracellular channel 1 (CLIC1), stimulated by retinoic acid gene 6 homolog (mouse) (STRA6)), cell proliferation and apoptosis (cyclin D2 (CCND2), growth arrest and DNA damageinducible, $\beta$ (GADD45B), macrophage migration inhibitory factor (glycosylation-inhibiting factor; MIF), replication factor $\mathrm{C}$ (activator 1) 4, $37 \mathrm{kDa}(R F C 4)$ ), cell structure (actin, $\beta(A C T B)$, motile sperm domain containing 3 (MOSPD3)), protein transport (sorting nexin 9 (SNX9)), and RNA (splicing factor, arginine/ serine-rich 9 (SFRS9), mago-nashi homolog, proliferation-associated (Drosophila) $(\mathrm{MAGOH})$, protein (Dna) (Hsp40) homolog, subfamily A, member 1 (DNAJA1), solute carrier family 22 (organic cation transporter), member 17 (SLC22A17)) and lipid synthesis (stearoylCoA desaturase $(\delta$-9-desaturase) $(S C D)$ ). Five further tags matched uncharacterised genes. From the remaining five unmatched tags, full sequences were determined for two tags using RACE. These two transcripts encoded a novel $3^{\prime}$ truncated aromatase variant (deposited under NCBI accession number DQ004742 and recently matched to Bt.4447), and an untranslated mRNA sequence recently matched to the UniGene cluster Bt.33875 (deposited under $\mathrm{NCBI}$ accession number AY999166). In addition, SAGE analysis of transcripts upregulated in the DF granulosa cells confirmed four known genes encoding cytochrome P450 aromatase (CYP19A1), glutathione $S$-transferase A2 (GSTA2), inhibin $\alpha$-subunit (INHA) and glia-derived nexin (SERPINE2), which regulate follicular E synthesis, antioxidant activity and extracellular tissue remodelling in the selected DF (Mihm et al. 1997, Sisco et al. 2003, Evans et al. 2004, Fayad et al. 2004).

(B) Granulosa cell transcripts downregulated in the DF compared with both the $\mathrm{COH}$ and SF SAGE libraries (Table 2): Out of the 16 tags downregulated in the DF, 14 tags matched characterised genes that encode proteins with cellular functions such as signalling (guanine nucleotide-binding protein (G-protein), $\beta$ polypeptide 2-like 1 (GNB2L1), phospholipase D family, member 3 $(P L D 3)$ ), proliferation (anaphase promoting complex subunit 4 (ANAPC4)), structure (actin, $\gamma 1$ (ACTG1)), protein synthesis (ribosomal proteins L21 (RPL21), L10a (RPL10A), L12 (RPL12), L3 (RPL3)), transport (adaptor-related protein complex 1, $\mu 2$-subunit $(A P 1 M 2))$, secretion (serglycin $(S R G N)$ ) and metabolism (F-box protein 10 (FBXO10)), nitrogen metabolism (glutamate dehydrogenase 1 (GLUD1)) and lipid synthesis, transport and metabolism (prosaposin (variant Gaucher disease and variant metachromatic leukodystrophy) $(P S A P)$, prostaglandin E synthase (PTGES), scavenger receptor class $B$, member 2 (SCARB2)). Only two of the identified genes, PTGES and PSAP, have previously been associated with ovarian function, specifically luteinisation of granulosa cells (Filion et al. 2001, McRae et al. 2005).

(C) Granulosa cell transcripts expressed at the intermediate levels in the DF SAGE library (Table 2): nine out of the twelve characterised transcripts downregulated in the DF, but lowest in the SF compared with the $\mathrm{COH}$ granulosa cell library, encoded proteins not previously associated with ovarian activity. These proteins have diverse cellular functions in signalling (calreticulin $(C A L R)$ ), metabolism (cytochrome $c$ oxidase subunit VIIb $(C O X 7 B)$, glutathione peroxidase 1 (GPX1)), DNA binding (high-mobility group nucleosomal binding domain 2 (HMGN2), poly( $\mathrm{rC}$ ) binding protein 1 $(P C B P 1))$, RNA synthesis (non-POU domain containing, octamer binding (NONO)), protein synthesis (Tu translation elongation factor, mitochondrial (TUFM)) and metabolism (heat shock $70 \mathrm{kDa}$ protein 8 (HSPA8), heat shock protein $90 \mathrm{kDa} \quad \beta$ (Grp94), member 1 (HSP90B1)) (Table 2). The remaining three transcripts encoded genes (inhibin, $\beta$ A (INHBA), hydroxy- $\delta$ 5 -steroid dehydrogenase, $3 \beta$ - and steroid $\delta$-isomerase 1 (HSD3B1), tyrosine 3-monooxygenase/tryptophan 5-monooxygenase activation protein, $\varepsilon$ polypeptide $(Y W H A E)$ ) previously found to show higher mRNA expression in the newly selected DF (Bao \& Garverick 1998, Sisco et al. 2003, Fayad et al. 2004; Table 2).

Nineteen out of the twenty characterised transcripts upregulated in the DF, but highest in the SF compared with the $\mathrm{COH}$ granulosa cell library, matched genes that encode ribosomal (17 genes) or other proteins (eukaryotic translation elongation factor $1 \alpha 1$ (EEF1A1), FinkelBiskis-Reilly murine sarcoma virus (FBR-MuSV) 
Table 2 SAGE tags differentially regulated $(P \leq 0.05)$ in granulosa cells of dominant follicles (DF) compared with the most oestrogenic cohort follicle $(\mathrm{COH})$ and the largest subordinate follicle (SF).

\begin{tabular}{|c|c|c|c|c|c|}
\hline Tag sequence & COH tags* & DF tags* & SF tags* & Gene symbol & UniGene number $^{+}$ \\
\hline \multicolumn{6}{|c|}{ (A) SAGE tags upregulated in the DF compared with both the $\mathrm{COH}$ and the SF } \\
\hline AGGCCCCTAC & $8890^{\mathrm{a}}$ & $35452^{b}$ & $28862^{\mathrm{C}}$ & INHA & 4897 \\
\hline GACAAGACTA & $3383^{\mathrm{a}}$ & $17025^{b}$ & $13431^{\mathrm{c}}$ & GSTA2 & 227 \\
\hline TATCCACTAA & $7651^{\mathrm{a}}$ & $13366^{\mathrm{b}}$ & $8543^{\mathrm{a}}$ & SERPINE2 & 12506 \\
\hline CAGTCAATAT & $7395^{\mathrm{a}}$ & $9517^{b}$ & $5696^{\mathrm{C}}$ & $\begin{array}{l}\text { AY999166 now } \\
\text { matched to: transcribed } \\
\text { locus }\end{array}$ & 33875 \\
\hline GCTCAACCAG & $2045^{a}$ & $2692^{\mathrm{b}}$ & $1818^{\mathrm{a}}$ & STRA 6 & 3196 \\
\hline TTGATGTTTG & $688^{\mathrm{a}}$ & $2408^{b}$ & $747^{\mathrm{a}}$ & CYP19A1 & 4447 \\
\hline TGTCTACATA & $531^{\mathrm{a}}$ & $1782^{b}$ & $1272^{\mathrm{C}}$ & Transcribed locus & 53423 \\
\hline AAGAAAATAG & $1003 *$ & $1555^{\mathrm{b}}$ & $606^{\mathrm{c}}$ & SNX9 & 5507 \\
\hline TTAGAATGTT & $472^{\mathrm{a}}$ & $1403^{b}$ & $949^{\mathrm{c}}$ & $\mathrm{MAGOH}$ & 53423 \\
\hline AACGCGGCCA & $256^{\mathrm{a}}$ & $1687^{\mathrm{b}}$ & $626^{\mathrm{C}}$ & MIF & 15528 \\
\hline GACCCCTTTT & $551^{\mathrm{a}}$ & $1138^{\mathrm{b}}$ & $606^{\mathrm{a}}$ & ACTB & 14186 \\
\hline TGATTTCACT & $197^{\mathrm{a}}$ & $1005^{\mathrm{b}}$ & $586^{\mathrm{C}}$ & Unmatched & \\
\hline GTGTTCCTCC & $118^{\mathrm{a}}$ & $720^{\mathrm{b}}$ & $384^{\mathrm{C}}$ & MOSPD 3 & 3028 \\
\hline AACTCCCAGC & $295^{a}$ & $645^{\mathrm{b}}$ & $222^{\mathrm{a}}$ & GADD $45 B$ & 4371 \\
\hline TCTGAATAGT & $295^{\mathrm{a}}$ & $569^{\mathrm{b}}$ & $222^{a}$ & OSAP & 25070 \\
\hline TTGTTGTTGA & $275^{\mathrm{a}}$ & $626^{\mathrm{b}}$ & $162^{a}$ & CALM2 & 12896 \\
\hline TACCCGCCGT & $0^{\mathrm{a}}$ & $645^{\mathrm{b}}$ & $343^{c}$ & CCND2 & 4895 \\
\hline AGGCССССТА & $39^{a}$ & $512^{\mathrm{b}}$ & $61^{\mathrm{a}}$ & Unmatched & \\
\hline CTCACAGGAT & $118^{\mathrm{a}}$ & $322^{b}$ & $101^{\mathrm{a}}$ & Transcribed locus & 15298 \\
\hline CTACCCAACG & $59^{\mathrm{a}}$ & $322^{\mathrm{b}}$ & $61^{\mathrm{a}}$ & CLIC1 & 49164 \\
\hline AGGGTGAAAC & $39^{\mathrm{a}}$ & $284^{\mathrm{b}}$ & $81^{\mathrm{a}}$ & SFRS9 & 30434 \\
\hline GAAAGATACA & $39^{\mathrm{a}}$ & $246^{\mathrm{b}}$ & $0^{\mathrm{a}}$ & $\begin{array}{l}\text { DQ004742 now matched } \\
\text { to CYP19A1 }\end{array}$ & 4447 \\
\hline TGACAGGGTG & $39^{a}$ & $190^{b}$ & $20^{\mathrm{a}}$ & Similar to $\mathrm{C} 17$ orf 49 & 7060 \\
\hline CCAATTTATC & $20^{\mathrm{a}}$ & $190^{\mathrm{b}}$ & $20^{\mathrm{a}}$ & $D N A J A 1$ & 3274 \\
\hline TAGAATCCAC & $20^{\mathrm{a}}$ & $209^{b}$ & $0^{\mathrm{a}}$ & Transcribed locus & 1411 \\
\hline ATGTGGTGGT & $0^{*}$ & $171^{\mathrm{b}}$ & $0^{\mathrm{a}}$ & RFC4 & 13925 \\
\hline ATGACCCATT & $0^{\mathrm{a}}$ & $152^{\mathrm{b}}$ & $0^{\mathrm{a}}$ & $S C D$ & 4798 \\
\hline GCGGCCCGGT & $0^{\mathrm{a}}$ & $133^{\mathrm{b}}$ & $0^{\mathrm{a}}$ & Unmatched & \\
\hline СTTCTGCCGG & $0^{\mathrm{a}}$ & $114^{\mathrm{b}}$ & $0^{\mathrm{a}}$ & SLC22A17 & 48982 \\
\hline ТАААТTТССС & $0^{\mathrm{a}}$ & $114^{\mathrm{b}}$ & $0^{\mathrm{a}}$ & Transcribed locus & 36212 \\
\hline TTGAAAATTA & $0^{\mathrm{a}}$ & $114^{\mathrm{b}}$ & $0^{a}$ & ANXA2 & 4314 \\
\hline \multicolumn{6}{|c|}{ (B) SAGE tags downregulated in the DF compared with both the $\mathrm{COH}$ and the SF } \\
\hline TTGCATTACC & $15990^{\mathrm{a}}$ & $11451^{\mathrm{b}}$ & $13068^{\mathrm{C}}$ & SRGN & 10209 \\
\hline GCCTGATGGG & $5350^{\mathrm{a}}$ & $3792^{\mathrm{b}}$ & $4706^{\mathrm{a}}$ & RPL21 & 5211 \\
\hline GCAGAGCTTT & $3678^{\mathrm{a}}$ & $2199^{\mathrm{b}}$ & $3050^{\mathrm{a}}$ & $G N B 2 L 1$ & 551 \\
\hline TGAGAACATT & $4209^{a}$ & $2029^{b}$ & $2666^{\mathrm{C}}$ & ACTG1 & 38667 \\
\hline GGCAAGCCCC & $2144^{\mathrm{a}}$ & $1479^{\mathrm{b}}$ & $2605^{\mathrm{a}}$ & RPL10A & 23381 \\
\hline ACATCATTGA & $2203^{a}$ & $1536^{\mathrm{b}}$ & $2101^{\mathrm{a}}$ & RPL12 & 15530 \\
\hline GGACCACTTA & $1495^{\mathrm{a}}$ & $891^{\mathrm{b}}$ & $1333^{\mathrm{a}}$ & $R P L 3$ & 3616 \\
\hline TGTATTTCTA & $1357^{a}$ & $720^{b}$ & $1151^{\mathrm{a}}$ & SCARB2 & 11224 \\
\hline TCССТАTTGC & $570^{\mathrm{a}}$ & $265^{b}$ & $909^{\mathrm{a}}$ & Unmatched & \\
\hline CGGTTGCTAT & $511^{\mathrm{a}}$ & $228^{\mathrm{b}}$ & $889^{\mathrm{c}}$ & PSAP & 5467 \\
\hline CAACTAGTGA & $590^{\mathrm{a}}$ & $133^{b}$ & $364^{a}$ & AP1M2 & 23342 \\
\hline CTGGGCCTAG & $216^{\mathrm{a}}$ & $57^{\mathrm{b}}$ & $303^{a}$ & PLD3 & 16204 \\
\hline ATGTCAAACT & $275^{a}$ & $38^{\mathrm{b}}$ & $202^{a}$ & $\begin{array}{l}\text { cDNA clone IMAGE } \\
8042713\end{array}$ & 30784 \\
\hline ACAGTGAGGA & $197^{\mathrm{a}}$ & $38^{\mathrm{b}}$ & $222^{\mathrm{a}}$ & PTGES & 49581 \\
\hline TCAGGAAGGA & $118^{\mathrm{a}}$ & $0^{\mathrm{b}}$ & $121^{\mathrm{a}}$ & ANAPC4 & 28388 \\
\hline ACTTAACCTG & $118^{\mathrm{a}}$ & $0^{\mathrm{b}}$ & $121^{\mathrm{a}}$ & GLUD1 & 55415 \\
\hline \multicolumn{6}{|c|}{ (C) SAGE tags downregulated in the DF compared with the $\mathrm{COH}$, further downregulated in the SF } \\
\hline TAAATGTGCA & $10483^{\mathrm{a}}$ & $8228^{\mathrm{b}}$ & $5352^{\mathrm{C}}$ & Transcribed locus & 20295 \\
\hline TTTAAGGTTT & $11604^{\mathrm{a}}$ & $4550^{\mathrm{b}}$ & $1232^{\mathrm{c}}$ & INHBA & 12760 \\
\hline AGACAAGAGT & $7356^{a}$ & $4228^{\mathrm{b}}$ & $3191^{\mathrm{C}}$ & Transcribed locus & 38177 \\
\hline AATAAAGTGC & $3816^{\mathrm{a}}$ & $2995^{\mathrm{b}}$ & $2161^{\mathrm{c}}$ & GPX1 & 4317 \\
\hline AAAAAAAAAA & $5153^{\mathrm{a}}$ & $2370^{b}$ & $141^{\mathrm{C}}$ & Multiple clusters $^{\ddagger}$ & \\
\hline CTGAGAATGT & $2439^{a}$ & $1801^{\mathrm{b}}$ & $1131^{\mathrm{C}}$ & CALR & 30105 \\
\hline GAAAAACATT & $2203^{a}$ & $1138^{\mathrm{b}}$ & $566^{\mathrm{C}}$ & HSPA8 & 12309 \\
\hline CAAAAAAAAA & $1868^{*}$ & $1156^{\mathrm{b}}$ & $202^{\mathrm{C}}$ & Multiple clusters & \\
\hline ATTGTTTATG & $1888^{\mathrm{a}}$ & $815^{\mathrm{b}}$ & $343^{\mathrm{c}}$ & HMGN2 & 1758 \\
\hline GAATATTTGT & $1554^{\mathrm{a}}$ & $815^{\mathrm{b}}$ & $404^{\mathrm{c}}$ & TUFM & 5344 \\
\hline TAAAAAAAAA & $1593^{\mathrm{a}}$ & $588^{\mathrm{b}}$ & $40^{\mathrm{c}}$ & Multiple clusters & \\
\hline GAAAAAAAAA & $1180^{a}$ & $777^{\mathrm{b}}$ & $182^{\mathrm{C}}$ & Multiple clusters & \\
\hline
\end{tabular}


Table 2 Continued.

\begin{tabular}{|c|c|c|c|c|c|}
\hline Tag sequence & COH tags* & DF tags* & SF tags* & Gene symbol & UniGene number $^{\dagger}$ \\
\hline GATTAACATT & $1180^{*}$ & $645^{\mathrm{b}}$ & $242^{\mathrm{c}}$ & YWHAE & 4035 \\
\hline TGTATAAAAA & $1141^{\mathrm{a}}$ & $588^{\mathrm{b}}$ & $81^{\mathrm{c}}$ & HSP90B1 & 8686 \\
\hline AAAACATATC & $944^{\mathrm{a}}$ & $455^{\mathrm{b}}$ & $61^{\mathrm{c}}$ & Unmatched & \\
\hline TTTGAAGAAA & $728^{\mathrm{a}}$ & $379^{\mathrm{b}}$ & $81^{\mathrm{c}}$ & COX7B & 48953 \\
\hline AACTTATTAA & $629^{\mathrm{a}}$ & $228^{\mathrm{b}}$ & $61^{\mathrm{c}}$ & NONO & 37860 \\
\hline AATTTTATTT & $452^{\mathrm{a}}$ & $209^{b}$ & $20^{\mathrm{c}}$ & PCBP1 & 4620 \\
\hline ACTAAAAAAA & $334^{\mathrm{a}}$ & $133^{b}$ & $0^{\mathrm{c}}$ & HSD3B1 & 64737 \\
\hline \multicolumn{6}{|c|}{ (D) SAGE tags upregulated in the DF compared with the $\mathrm{COH}$, further upregulated in the SF } \\
\hline GCCGGCCCGG & $2990^{\mathrm{a}}$ & $4152^{\mathrm{b}}$ & $5999^{\mathrm{C}}$ & RPS15 & 4832 \\
\hline AGACAGACAG & $1357^{*}$ & $4417^{\mathrm{b}}$ & $5938^{\mathrm{c}}$ & EEF1A1 & 3573 \\
\hline TCCGTGCACC & $2399^{a}$ & $3413^{b}$ & $4807^{c}$ & RPS11 & 3626 \\
\hline AAGCCCAGCG & $2557^{\mathrm{a}}$ & $3242^{b}$ & $4302^{c}$ & RPS16 & 2686 \\
\hline CTGCCCAGCG & $1180^{\mathrm{a}}$ & $3394^{b}$ & $5009^{c}$ & RPL32 & 21534 \\
\hline СССАGССАСТ & $1298^{\mathrm{a}}$ & $3469^{b}$ & $4282^{c}$ & RPS19 & 7648 \\
\hline TTGGCTGCCC & $531^{\mathrm{a}}$ & $2256^{\mathrm{b}}$ & $3555^{\mathrm{c}}$ & RPS14 & 49145 \\
\hline GCTGCСАTCC & $983^{\mathrm{a}}$ & $1953^{b}$ & $2888^{c}$ & RPL28 & 48857 \\
\hline GTTCCCTGGC & $551^{*}$ & $1972^{b}$ & $2646^{\mathrm{c}}$ & FAU & 4618 \\
\hline CCCACAAGGT & $1141^{\mathrm{a}}$ & $1668^{b}$ & $2323^{\mathrm{c}}$ & RPL27 & 4721 \\
\hline GCAGAGTTCG & $393^{\mathrm{a}}$ & $1630^{\mathrm{b}}$ & $2848^{\mathrm{c}}$ & RPS6 & 7908 \\
\hline GATAAGGCAG & $747^{\mathrm{a}}$ & $1725^{\mathrm{b}}$ & $2282^{\mathrm{c}}$ & RPL4 & 48893 \\
\hline CTGCAATACG & $846^{\mathrm{a}}$ & $1270^{b}$ & $2525^{c}$ & RPL5 & 7052 \\
\hline GTGTTGCACA & $669^{a}$ & $1384^{\mathrm{b}}$ & $2201^{\mathrm{c}}$ & RPS13 & 2623 \\
\hline TCGGTCTGGG & $59^{a}$ & $1611^{b}$ & $2545^{\mathrm{c}}$ & RPS2 & 48814 \\
\hline GGCCGCGTTC & $354^{\mathrm{a}}$ & $1422^{b}$ & $2080^{c}$ & RPS17 & 26469 \\
\hline GGAGGCGCTA & $216^{\mathrm{a}}$ & $1062^{b}$ & $2141^{\mathrm{c}}$ & RPL24 & 49154 \\
\hline ACCGTGCGCA & $118^{\mathrm{a}}$ & $1138^{\mathrm{b}}$ & $2040^{c}$ & RPS5 & 1874 \\
\hline CAGTCTCTCA & $315^{\mathrm{a}}$ & $1232^{b}$ & $1737^{\mathrm{C}}$ & RPS10 & 49036 \\
\hline AGCCGCACCA & $79^{\mathrm{a}}$ & $1175^{\mathrm{b}}$ & $1899^{\mathrm{C}}$ & RPL18 & 4842 \\
\hline TTCAGCTCCA & $79^{\mathrm{a}}$ & $1138^{\mathrm{b}}$ & $1737^{\mathrm{C}}$ & RPS7 & 7187 \\
\hline CCGGTCGCCC & $98^{\mathrm{a}}$ & $891^{\mathrm{b}}$ & $1313^{\mathrm{c}}$ & RPS9 & 52718 \\
\hline CCCATCCGAA & $216^{\mathrm{a}}$ & $739^{\mathrm{b}}$ & $1232^{\mathrm{c}}$ & RPL26 & 49129 \\
\hline TCTATATTGC & $118^{\mathrm{a}}$ & $474^{\mathrm{b}}$ & $1151^{\mathrm{c}}$ & Unmatched & \\
\hline ATCCGGCGCC & $79^{\mathrm{a}}$ & $265^{\mathrm{b}}$ & $606^{\mathrm{c}}$ & TCEB2 & 49100 \\
\hline TCСТАТTGСС & $39^{\mathrm{a}}$ & $228^{\mathrm{b}}$ & $545^{\mathrm{c}}$ & Unmatched & \\
\hline GACTATAGCC & $20^{*}$ & $171^{\mathrm{b}}$ & $485^{\mathrm{c}}$ & Multiple clusters & \\
\hline СCTGGGCTCC & $0^{\mathrm{a}}$ & $133^{\mathrm{b}}$ & $364^{\mathrm{c}}$ & Transcribed locus & 66365 \\
\hline
\end{tabular}

a, b, c Different superscripts indicate significant differences $(P \leq 0.05)$ between SAGE libraries.

*The number of tags in each library was normalised to a total of $10^{6}$ tags. ${ }^{+} A$ minority of tags (18/93) matched with more than one UniGene cluster; in this case the cluster with the complete mRNA sequence and/or the majority of sequences containing the tag is presented. ${ }^{*}$ Five tags could not be matched reliably to one UniGene cluster, because several clusters contained a complete mRNA sequence or similar number of sequences containing the tag sequence.

ubiquitously expressed (FAU)) regulating protein biosynthesis, while the remaining transcript matched the gene transcription elongation factor B (SIII), polypeptide 2 (18 kDa, elongin B; TCEB2), which regulates protein metabolism (Table 2).

\section{Real-time PCR analysis of genes with higher transcript levels in the DF compared with both the $\mathrm{COH}$ and SF granulosa cell SAGE libraries}

The genes analysed using real-time PCR contained most of the characterised transcripts upregulated in the DF based on the SAGE analysis (Fig. 3). The results confirmed that seven genes (CYP19A1, INHA, CCND2, GADD45B, SFRS9, OSAP and DQ004742) show upregulated $(P \leq 0.05)$ mRNA expression in the DF compared with both the $\mathrm{COH}$ (for OSAP $P=0.06$ ) and SF granulosa cells. An additional seven transcripts, encoded by MIF, RFC4, ANXA2, CALM2, CLIC1,
GSTA2 and SLC22A17, were upregulated $(P \leq 0.05)$ in the DF compared with the SF, and two transcripts (STRA6, AY999166) tended to be upregulated $(0.05<P \leq 0.07)$ in the DF compared with the $\mathrm{COH}$ granulosa cells. Although statistical significance was not always reached, average transcript levels determined using real-time PCR were higher in the DF compared with both the $\mathrm{COH}$ and SF granulosa cells for 16 out of the 18 tested genes. mRNA expression levels for LHCGR, included as a positive control, were also higher $(P \leq 0.05)$ in the DF compared with both the $\mathrm{COH}$ and SF granulosa cells.

\section{Discussion}

In this study, we have identified changes in the granulosa cell transcriptome as the DF differentiates from the FSHdependent cohort and begins its $\mathrm{LH}$-dependent final development. This approach differs from that of the 


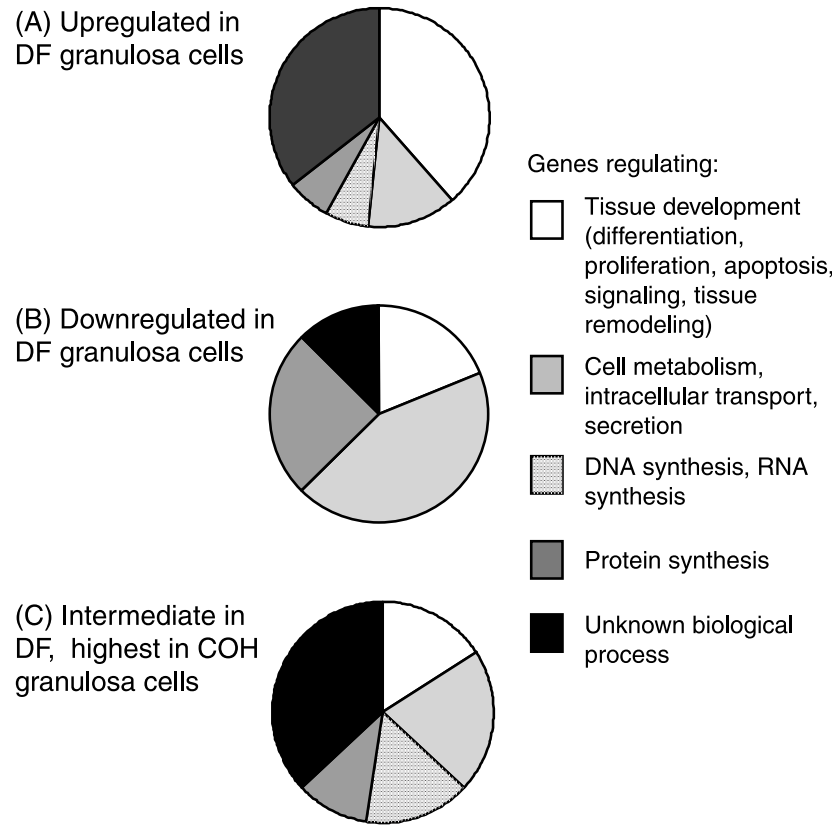

(D) Intermediate in DF, highest in SF granulosa cells

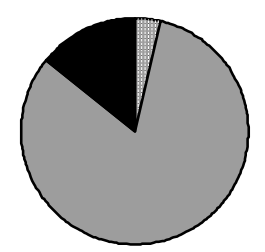

Figure 2 Ontology analysis of genes encoded by transcripts found to be upregulated (A), downregulated (B) or expressed at the intermediate levels (C and D) in the granulosa cell SAGE library of newly selected dominant follicles (DF) compared with the libraries of the most oestrogenic cohort $(\mathrm{COH})$ and the largest subordinate follicle (SF).

previous studies, which used the bovine DF model to identify genes important for DF survival versus subordinate atresia at the onset of dominance (Sisco et al. 2003, Evans et al. 2004, Fayad et al. 2004). This study has identified more than 80 new genes regulated in the DF, and this knowledge may be very relevant for the study of abnormalities occurring during DF development (such as premature atresia or cystic degeneration) in post partum cows, but also in other monovulatory species such as humans. It is also likely that a number of identified genes are involved in the regulation of large follicle development in multiovulatory species. Thus, understanding the roles and regulation of these new genes may become relevant to the development of new approaches to diagnose and treat infertility not only in single-ovulating but also in multi-ovulatory species with agricultural importance such as the pig.

The $\mathrm{COH}$ recovered for this study most likely represent the FSH-'dependent' development stage of the future DF. This conclusion is based on the previously described timing of growth of the first follicle wave of the oestrous cycle, intrafollicular hormone concentrations and the fact that, while morphologically unselected and still FSH 'dependent', the most oestrogenic cohort follicle 1-2 days after wave emergence will most likely become the DF (Mihm et al. 1997, 2000, Austin et al. 2001). Growth characteristics and differences in diameter, steroid concentrations and oestrogenic activity established in this study showed the higher differentiation state of the DF recovered at or shortly after the onset of dominance in accordance with previous characterisations of selected DFs (Ginther et al. 2003, Mihm \& Bleach 2003). As serum concentrations of FSH decline to nadir concentrations at this time, the DF is known to switch from a relative $\mathrm{FSH}$ to $\mathrm{LH}$ dependence of growth and $\mathrm{E}$ production (Mihm \& Bleach 2003). This functional switch is clearly paralleled by the acquisition of $\mathrm{LH}$ receptors and increased $\mathrm{LH}$ binding in the DF granulosa cells (ligand-binding study: Ireland \& Roche 1983; in situ hybridisation studies: Evans \& Fortune 1997, Bao \& Garverick 1998; real-time PCR studies: Evans et al. 2004; this study). However, it appears that transcript levels for $L H C G R$ are relatively low in granulosa cells of the newly selected DF, as mRNA expression was not detected using the SAGE analysis in this study and in another study using in situ hybridisation (Evans \& Fortune 1997). SAGE tags matched to $L H C G R$ were only infrequently found in murine granulosa cells of preovulatory follicles where maximum levels would be expected (McRae et al. 2005). Therefore, the SAGE technique may not be sensitive enough to detect very low levels of $L H C G R$ transcripts, in contrast to real-time PCR.

This study showed that the majority of characterised transcripts upregulated in the DF granulosa cells are encoded by genes that regulate $\mathrm{E}$ synthesis, cell proliferation and survival, signalling, organ development or extracellular tissue remodelling. All these functions are important for tissue development which could directly support the enhanced growth and steroidogenesis characteristic of the DF. The combination of SAGE and real-time PCR clearly identified four genes not previously associated with ovarian function or DF development (CCND2, GADD45B, OSAP and SFRS9) and one novel gene (aromatase variant DQ004742), which show upregulated mRNA expression in the DF compared with both the $\mathrm{COH}$ and SF granulosa cells. Cyclin D2 regulates the G1 to $S$ transition within the cell cycle promoting proliferation, and its expression is regulated by $\mathrm{FSH}$, E and IGF (Robker \& Richards 1998, Kadakia et al. 2001). It may not be surprising that the DF shows the highest CCND2 transcript levels, since it is exposed to the highest free IGF concentrations and the highest intrafollicular E and oestrogen receptor $\beta$ expression (Mihm et al. 2000, Beg et al. 2002, Evans et al. 2004). Similarly, the gene product GADD45 may act as a potential survival factor in the growing DF, as it is involved in DNA damage repair and control of genomic stability, and has also anti-apoptotic properties (Sheikh et al. 2000, De Smaele et al. 2001). The splicing factor arginine/serine-rich 9 encoded by SFRS9 

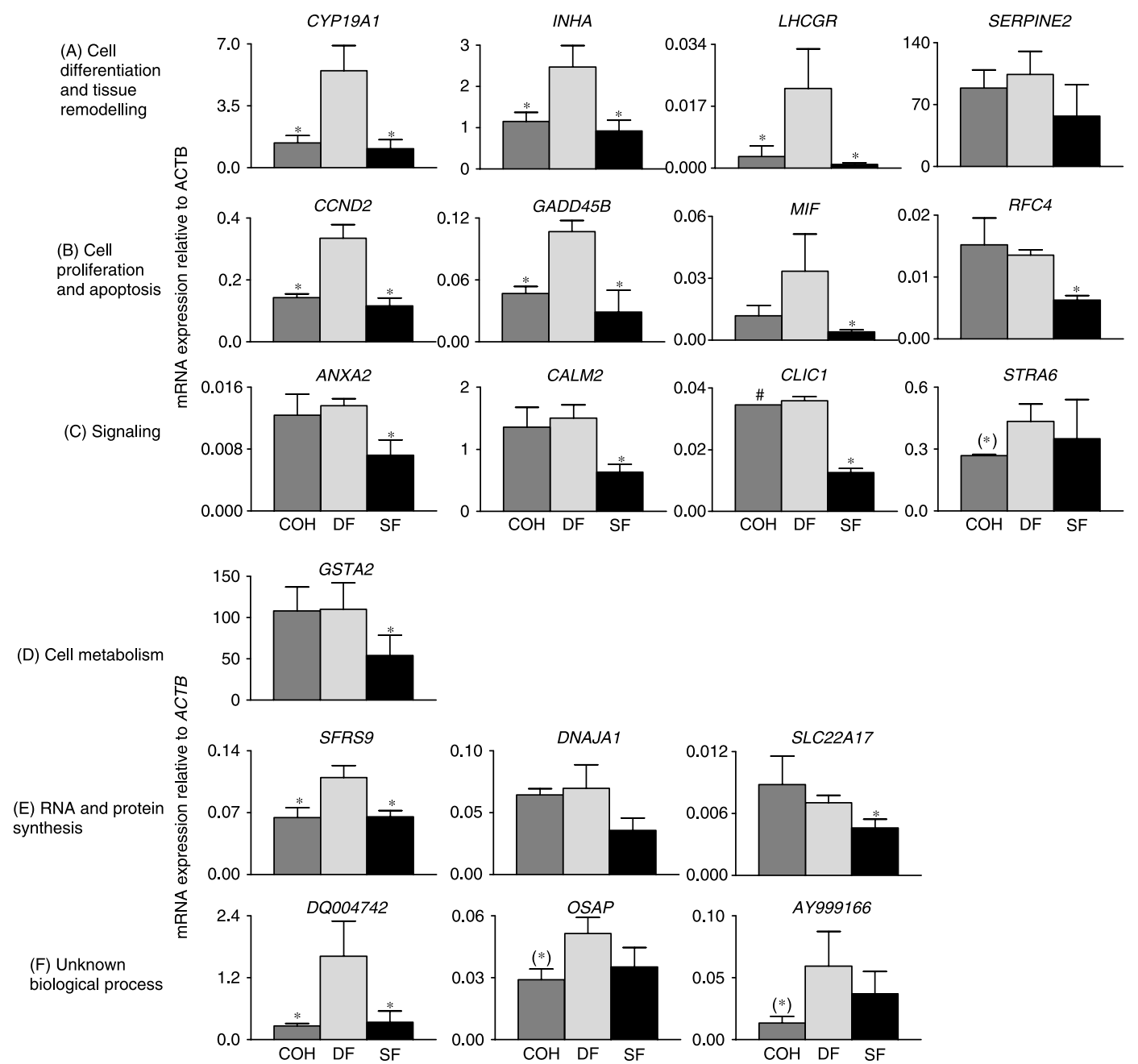

Figure 3 Semiquantitative real-time PCR analysis of granulosa cell mRNA expression in the most oestrogenic cohort (COH, dark grey bars), dominant (DF, light grey bars) and the largest subordinate follicle (SF, black bars) for genes regulating tissue development (A-C), cellular metabolism (D), RNA and protein synthesis $(\mathrm{E})$ or unknown biological processes $(\mathrm{F})$; three to four individual $\mathrm{COH}$, DF or SF were analysed. *mRNA expression differed $(P \leq 0.05)$ or ${ }^{(*)}$ tended to differ $(0.05<P \leq 0.07)$ from DF. ${ }^{\#}$ Only a pooled cohort sample was available for analysis.

regulates constitutive splicing of RNA and modulation of the selection of alternative splice sites (Screaton et al. 1995). Interestingly, bovine granulosa cells from large follicles express differentially spliced gonadotrophin receptor mRNA variants (LHCGR: Kawate \& Okuda 1998; FSHR: Rajapaksha et al. 1996), and such differential expression of splice variants may modify receptor response in growing follicles (Babu et al. 2000). In fact, this study has identified a new $3^{\prime}$ truncated aromatase mRNA splice variant (DQ004742) expressed in bovine granulosa cells. However, this transcript variant, with orthologues in the sheep, pig and human EST libraries, consists only of exons $1-5$ of the aromatase gene, and thus may have no further function following translation (Levallet et al. 1998). A new gene with so far unknown functions, $O S A P$, identified in mouse preovulatory follicles, may be a marker of differentiated follicle development, specifically of increased $\mathrm{E}$ synthesis, with gene expression responding to gonadotrophic stimulation (Hennebold et al. 2000,
Tanaka et al. 2003). We propose, therefore, that the new genes identified by the SAGE and real-time PCR analyses, which show enhanced expression in the DF, may regulate proliferation, prevention of apoptosis or DNA damage, RNA synthesis and unknown processes associated with enhanced steroidogenesis in granulosa cells of the DFat the onset of its LH-dependent development. It needs to be determined in the future whether such genes are regulated by $\mathrm{LH}$ or, indeed, by $\mathrm{E}$, as mRNA expression is upregulated in the DF at the same time as increased $\mathrm{LH}$ receptor transcript levels and enhanced $\mathrm{E}$ synthesis are detected.

Based on the results from the SAGE and real-time PCR analyses, an additional four new tissue development genes (ANX2, CALM2, CLIC1 and MIF) and one known gene, GSTA2, are very good candidates for further experiments to determine their positive roles in DF granulosa cell proliferation, survival and steroidogenesis. High levels of annexin A2, a member of the family of calcium-binding proteins with multiple roles in 
membrane function, phospholipid transport and cell signalling (Camors et al. 2005) have been detected in cells during the $\mathrm{G} 1$ to $\mathrm{S}$ transition phase of mitosis (Chiang et al. 1993). Calmodulin can affect gonadotrophinregulated granulosa cell steroidogenesis through its calcium-binding properties in the laboratory rodents (Carnegie \& Tsang 1984, Stocco et al. 2002), and macrophage migration inhibitory factor has antioxidant and anti-apoptotic activities (Mitchell \& Bucala 2000, Nguyen et al. 2003) and may regulate murine follicular development and ovulation (Matsuura et al. 2002). In contrast to the previous three genes, expression of the chloride intracellular channel protein 1, which localises to internal organelles and is involved in ion transport (Landry et al. 1993), has never been described in ovarian cells. For these genes, both SAGE and real-time PCR analyses showed significantly higher mRNA expression in the DF compared with the SF granulosa cells, and absolutely higher mRNA expression levels in the DF compared with the $\mathrm{COH}$ granulosa cells. Overall, the quantitative nature of the data derived from the SAGE libraries appears to be reliable. This is seen most clearly in the accord between results from SAGE and real-time PCR with data from 16 out of the 18 tested genes showing absolutely higher mRNA expression levels in the DF. Also, findings from this study confirmed data for five genes (CYP19A1, GSTA2, HSD3B1, INHBA and SERPINE2) previously generated using very different genomic and molecular techniques, such as suppressive subtraction hybridisation, cDNA microarray or in situ hybridisation (Bao \& Garverick 1998, Sisco et al. 2003, Evans et al. 2004, Fayad et al. 2004). Complete confirmation of SAGE results by real-time PCR may not be expected, since the SAGE technique does not account for biological variation due to pooling of RNA samples. Thus, a markedly greater sample size may be required when using real-time PCR to demonstrate significant differences in gene expression for the group of genes, in which mean profiles show absolute, but not statistical, increases in the DF. In addition, the two molecular techniques may target different transcript regions, $3^{\prime}$ transcript variants may exist and unequal amplification efficiencies may prevent the detection of low transcript numbers, preventing complete concordance of results.

The inclusion of the $\mathrm{FSH}$-dependent $\mathrm{COH}$ in this study of DF development extends previously published data for three genes, HSD3B1, INHBA and YWHAE (Bao \& Garverick 1998, Sisco et al. 2003, Fayad et al. 2004). While the higher transcript levels in the DF versus SF granulosa cells were confirmed for all three genes, SAGE analysis showed the highest expression in the $\mathrm{COH}$ and declining expression in the DF granulosa cell SAGE library. This occurs in parallel with declining FSH serum concentrations (Mihm \& Bleach 2003). The granulosa cell mRNA expression for INHBA is FSH responsive in the laboratory rodent (Aloi et al. 1995), but whether expression of all three genes is directly regulated by FSH during bovine cohort growth needs to be determined in the future.

Finally, a large number of transcripts encoding genes that regulate protein synthesis are abundantly expressed and regulated in the DF granulosa cells at the onset of dominance based on the SAGE analysis. Our findings of high expression (the top 10 abundant transcripts encoding ribosomal proteins represent between 3.3 and $4.5 \%$ of the granulosa cell transcriptome) concur with other SAGE studies (Angelastro et al. 2002) and other studies profiling gene expression in ovarian tissue (Stanton et al. 2002). However, almost all transcripts upregulated in the DF compared with the $\mathrm{COH}$ granulosa cells, but expressed at the highest levels in the SF granulosa cells, encode ribosomal proteins (Table 2). The finding of such differential expression in granulosa cells from individual follicles of different developmental stages ( $\mathrm{FSH}$ or $\mathrm{LH}$ dependence) and fates (dominance or atresia) is a completely new result, and may indicate that the regulation of cellular protein synthesis is an important feature of antral follicle growth, signalling the onset of a new intracellular program (Ludwig \& Tenhaken 2001). Ribosomal proteins may be involved in differentiation and apoptosis, two cellular programmes clearly important for the DF and SF respectively. For example, the DF shows reduced RPS15 transcript levels similar to differentiating rat neuronal cells (Angelastro et al. 2002). Conversely, several members of the large and small ribosomal subunit protein families have been shown to promote apoptosis onset in the mammalian cell model systems (Khanna et al. 2000, Coutts \& La Thangue 2006), and upregulated mRNA expression in the SF may, therefore, be part of the mechanism for the initiation of granulosa cell apoptosis.

In conclusion, the combination of genomic profiling with SAGE followed by real-time PCR identified numerous new genes that are candidates for specific cellular and molecular hypotheses with regard to their direct roles in DF differentiation. Thus, enhanced expression of the proliferative gene CCND2 and the anti-apoptotic gene GADD45B in granulosa cells may support further growth of the DF, while enhanced expression of CYP19A1, DQ004742, INHA or OSAP may support the increased $E$ synthesising capacity characteristic of DF. In addition, this study has highlighted nuclear events such as RNA splicing which are regulated in the DF at the onset of dominance. We propose that the causative roles of any of these candidate genes in DF differentiation will have to be established in in vivo models of DF growth, using intrafollicular gene silencing or enhancing techniques yet to be validated by the research groups working with this model. Elucidating the key cellular pathways for physiological DF differentiation will allow hypothesis-driven investigations of aberrations of DF development, and thus the bovine model may also become invaluable for the testing of candidate genes and proteins influencing DF selection and development in the woman. 


\section{Materials and Methods}

\section{Animal model and follicle recovery}

Eight multiparous (2-11 lactations), non-lactating HolsteinFriesian dairy cows in the luteal phase of the oestrous cycle were treated with a short-term (3-6 days) intravaginal progesterone device (EAZI-BREED CIDR; Animal Reproductive Technologies Ltd, Leominster, UK) and injected with the prostaglandin F2 $\alpha$ analogue luprostiol (PGF; Prosolvin; Intervet Milton Keynes, UK) before device withdrawal to induce precisely timed luteolysis, oestrus and ovulation. From the time of PGF treatment, ovarian follicular development was monitored daily by transrectal ultrasound scanning using a 7.5 $\mathrm{MHz}$ transducer to determine the time of ovulation. 'Emergence' (sudden appearance) and subsequent growth of follicles from $3 \mathrm{~mm}$ in diameter belonging to the first cohort of the next oestrous cycle was monitored using ultrasound every $12 \mathrm{~h}$ until recovery of (1) cohort follicles before the DF can be identified (four cows) and (2) the DF and SF at or just after the time when their divergence in growth was determined (four cows). This time point, which defines the onset of dominance, was reached when the DF had a minimum size of $8 \mathrm{~mm}$ at the last ultrasound examination, was larger and grew faster over the last 24-h period than the next largest follicle (Ginther et al. 1997, Mihm \& Bleach 2003). The DF selection process and the subsequent 3- to 4-day growth phase (Mihm et al. 2006) are similar for non-ovulatory and ovulatory DF (Roche et al. 1998).

Of the recovered cohort follicles, the follicle with the highest absolute concentrations of $E$ in the follicular fluid, which was also the largest in three out of four cows, was subsequently selected for gene expression profiling. This follicle became the $\mathrm{COH}$ representing the $\mathrm{FSH}-$ 'dependent' stage of the future DF, because the most oestrogenic follicle 1-2 days before the onset of dominance will become the DF (Mihm et al. 2000). Diameter changes of the $\mathrm{COH}, \mathrm{DF}$ and SF until recovery determined using ultrasonography are shown in Fig. 1. Ovaries were removed from cows within $2.5 \mathrm{~h}$ of the last ultrasound examination following slaughter in the post-mortem facility of the Faculty of Veterinary Medicine, University of Glasgow. Transrectal ultrasound scanning was carried out under the license awarded by the Home Office, UK, according to the 'Animals and Procedures Act 1986'.

\section{Follicle dissection and recovery of follicular fluid and granulosa cells}

Following slaughter, ovaries were removed and placed in $0.05 \mathrm{M}$ ice-cold PBS for the short transport to the laboratory. DFs and SF were identified by matching ultrasound records with ovarian diagrams, follicle surface measurements and calliper measurements after dissecting follicles free from stroma. In cows where ovaries were recovered before the DF could be identified morphologically, five to eight follicles belonging to the new cohort were dissected. The follicular fluid was aspirated gently from all the dissected follicles using a 20 or 25 gauge needle attached to a $1 \mathrm{ml}$ syringe to minimise aspiration of granulosa cells. The follicular fluid was then stored on ice until dissections were completed, and frozen at $-20{ }^{\circ} \mathrm{C}$ until assayed for $\mathrm{E}$ and progesterone concentrations.
Steroid concentrations were subsequently used to identify $\mathrm{COH}$ (see above) and confirm DF and SF identities.

Granulosa cells were collected by extensive flushing of the cavity of excised follicles with PBS, centrifuged for $5 \mathrm{~min}$ at $700 \mathrm{~g}$ and washed twice with PBS. The granulosa cell pellet was re-suspended in $400 \mu \mathrm{l}$ TRIzol Reagent (Invitrogen Ltd) for the extraction of total RNA. Total time from ovary recovery to granulosa cell RNA extraction was 30-45 min, similar to other successful studies of granulosa cell gene expression in bovine follicles (Evans et al. 2004, Mihm et al. 2006).

\section{Follicular fluid steroid analysis}

E concentrations in the unextracted follicular fluid samples were determined using a validated RIA (Mihm et al. 1997). Sensitivity of the assay was $0.04 \mathrm{pg} /$ tube, and the mean intraassay $(n=4-6)$ and inter-assay $(n=2)$ coefficients of variation (CV) for a $45 \mathrm{pg} /$ tube quality control sample were 9.1 and $12.2 \%$ respectively. $P$ concentrations in the unextracted follicular fluid samples were determined using a validated RIA (Ireland \& Ireland 1994, Mihm et al. 2006). Sensitivity of the assay was $0.01 \mathrm{ng} /$ tube, and the mean intra-assay $\mathrm{CV}(n=5)$ for a $1.4 \mathrm{ng} /$ tube quality control sample was $10.5 \%$.

\section{Construction of SAGE libraries}

Total RNA was extracted from granulosa cells using TRIzol reagent, according to the manufacturer's instructions. Poly $(A)^{+}$ RNA was isolated from equal amounts of RNA pooled from four individual follicles at the $\mathrm{COH}$, SF and DF stages using oligo dT cellulose (Invitrogen) or the Oligotex mRNA Mini Kit (Qiagen Ltd). The SAGE libraries were constructed from poly (A) ${ }^{+}$RNA as described previously (Velculescu et al. 1995, O'Shaughnessy et al. 2003, McRae et al. 2005). The ditags were amplified in two different stages of 23 cycles and 10 or 11 cycles using nested biotinylated primers. Concatemers were cloned into the Sphl site of the pZErO-1 vector (Invitrogen) and transfected into DH10B cells (Invitrogen). Selected clones were amplified using PCR and sequenced directly as described previously (Shires et al. 2001, O'Shaughnessy et al. 2003) using the BigDye terminator v1.1 and the ABI Prism 3100 Genetic Analyzer (Applied Biosystems, Warrington, UK). Fourteen-nucleotide SAGE tags were extracted from sequence data, and the frequency of tags was analysed using SAGE 2000 software (http://www.sagenet.org/protocol/index. htm). A total of 50844,52747 and 49512 14-nucleotide SAGE tags were sequenced in the $\mathrm{COH}$, DF and SF libraries respectively. The original SAGE data from the $\mathrm{COH}$, DF and SF libraries can be accessed at http://www.ncbi.nlm.nih.gov/ SAGE/ in the Gene Expression Omnibus repository under GSM48351, GSM48352 and GSM48353.

\section{Generation of full sequence from SAGE tags}

For two unmatched SAGE tags (GAAAGATACA and CAGTCAATAT), the full sequence was generated $3^{\prime}$ and $5^{\prime}$ from the tag sequence using pooled bovine granulosa cell RNA and the rapid amplification of complementary ends (RACE) technique (SMART RACE cDNA amplification kit; BD Biosciences, Cowley, UK; Chen et al. 2000, O'Shaughnessy et al. 2003). 
For initial $3^{\prime}$ RACE reactions, the SAGE tag plus six degenerate nucleotides at the $5^{\prime}$ end acted as the gene-specific primer for PCR. The sequences obtained were subsequently analysed using real-time PCR (see below).

\section{Semiquantitative real-time PCR (real-time PCR)}

Relative abundance of 19 selected transcripts was measured in RNA extracted from granulosa cells of individual $\mathrm{COH}$, DF and
SF by real-time PCR. Transcripts were chosen on the basis of SAGE analysis, except for $L H C G R$ (encoding the $\mathrm{LH}$ receptor) which is a marker gene and protein for DF differentiation (Ireland \& Roche 1983, Bao et al. 1997, Evans et al. 2004) and was chosen to physiologically validate real-time PCR results. The samples of granulosa cell RNA used for real-time PCR were taken from the same RNA used for the construction of the SAGE libraries, following removal of residual genomic DNA by DNase treatment (DNA-free DNase Treatment and Removal

Table 3 Sequences of primers and probes used for quantitative real-time PCR.

\begin{tabular}{|c|c|c|c|}
\hline Gene & Accession no. & Primer/probe* & Sequences $5^{\prime}$ to $3^{\prime}$ \\
\hline \multicolumn{4}{|l|}{ Housekeeping gene } \\
\hline \multirow[t]{3}{*}{$A C T B$} & \multirow[t]{3}{*}{ AY141970 } & $\mathrm{F}$ & GTCATCACCATCGGCAATGA \\
\hline & & $\mathrm{R}$ & CGTGAATGCCGCAGGATT \\
\hline & & $\mathrm{P}$ & CGСTGСССTGAGGСТСТСТTССА \\
\hline \multicolumn{4}{|l|}{ Cell differentiation and tissue remodeling } \\
\hline \multirow[t]{3}{*}{ CYP19A1 } & \multirow[t]{3}{*}{ NM174305 } & $\mathrm{F}$ & CATAGATTTCGCCACTGAGTTGAT \\
\hline & & $\mathrm{R}$ & GCATTTCCAATATGCACTGGTTT \\
\hline & & $\mathrm{P}$ & $\begin{array}{l}\text { TTGCTGAGAAACGTGGTGAACTTACAAGAGA- } \\
\text { GAA }\end{array}$ \\
\hline \multirow[t]{3}{*}{ INHA } & \multirow[t]{3}{*}{ NM174094 } & $\mathrm{F}$ & CTCGGATGGAGGTTACTCTTTTAAGT \\
\hline & & $\mathrm{R}$ & GATTCCСTTAGATGCAAGCACAGT \\
\hline & & $P$ & TGAGATGGTGCCCAACСTTCTCACC \\
\hline \multirow[t]{2}{*}{$L H C G R$} & \multirow[t]{2}{*}{ U20504 } & $\mathrm{F}$ & TGACCATGGCCCGTCTAAAA \\
\hline & & $\mathrm{R}$ & TACTACCCAAAGCAATTTATAGATTCAATG \\
\hline \multirow[t]{3}{*}{ SERPINE2 } & \multirow[t]{3}{*}{ NM174669 } & $\mathrm{F}$ & TTCTCCGCATGGGATTGC \\
\hline & & $\mathrm{R}$ & GAGACGATGGCCTTGTTGATCT \\
\hline & & $P$ & CGGCGTGAACGGAGTCGGTAAGA \\
\hline \multicolumn{4}{|l|}{ Cell proliferation and apoptosis } \\
\hline \multirow[t]{2}{*}{ CCND2 } & \multirow[t]{2}{*}{ CB455384 } & $\mathrm{F}$ & TGCCCCAGTGCTCСТACTTC \\
\hline & & $\mathrm{R}$ & CGGGTACATGGCAAACTTGA \\
\hline \multirow[t]{2}{*}{$G A D D 45 B$} & \multirow[t]{2}{*}{ AV616939 } & $\mathrm{F}$ & TACGAGTCGGCCAAGCTGAT \\
\hline & & $\mathrm{R}$ & GTCСТССТСТTССТCGTCGAT \\
\hline \multirow[t]{2}{*}{ MIF } & \multirow[t]{2}{*}{ CO890360 } & $\mathrm{F}$ & GCATTAGCCCGGACAGGAT \\
\hline & & $\mathrm{R}$ & GGCCСTCAGGCGAAGGT \\
\hline \multirow[t]{2}{*}{ RFC4 } & \multirow[t]{2}{*}{ CK972781 } & $\mathrm{F}$ & GGCTCTTTCGACAAACTAGAAGCT \\
\hline & & $\mathrm{R}$ & CATGGAGTTGATTTACAAGTTGAGTTG \\
\hline Intracellular signalling & & & \\
\hline ANXA2 & NM174716 & $\mathrm{F}$ & AGCTCAGTTTGGAGGGTGATCA \\
\hline & & $\mathrm{R}$ & CCGCTCAGCATCAAAGTTAGTGT \\
\hline CALM2 & CK979290 & $\mathrm{F}$ & AGCAGAGCTTCGCCATGTG \\
\hline & & $\mathrm{R}$ & TCTGСTTCССТGATCATTTCATC \\
\hline CLIC1 & ВТ021003 & $\mathrm{F}$ & CACСTTCAATGTCACCACTGTTG \\
\hline & & $\mathrm{R}$ & TCAGTGCCATACAGCAGGAAAG \\
\hline STRA6 & CR456296 & $\mathrm{F}$ & GCСTGCTGCCGCTTAGAG \\
\hline & & $\mathrm{R}$ & TGACTGGCTGGCСTCCAT \\
\hline Cell metabolism & & & \\
\hline GSTA2 & U49179 & $\mathrm{F}$ & GTGCCCACСТGCTGAAAAA \\
\hline & & $\mathrm{R}$ & TTTTCAAATGCAGGGAGATAACG \\
\hline RNA and protein synthesis & & & \\
\hline SFRS9 & CR456210 & $\mathrm{F}$ & GTGCССTTCGCСTTCGT \\
\hline & & $\mathrm{R}$ & GGCCATAATCATAACCGTTCCTT \\
\hline$D N A J A 1$ & CB441342 & $\mathrm{F}$ & ATGGAGATATCAAGTGTGTGCTAAATG \\
\hline & & $\mathrm{R}$ & CTCAGGAAAGTTTACCTTAAATTCAATG \\
\hline$S L C 22 A 17$ & BI534865 & $\mathrm{F}$ & CGATTTCTTCAGCGAATGATCAC \\
\hline & & $\mathrm{R}$ & TCСТСААТСТGTCGСТTСАСТАTC \\
\hline Unknown biological process & & & \\
\hline New aromatase sequence matched to UniGene & DQ004742 & $\mathrm{F}$ & TGGATGGTACTGAAATTTTCATTCTC \\
\hline & & $\mathrm{R}$ & ACAAAAAAGTGTATCTTTCCATGAGTTC \\
\hline OSAP & CB467434 & $\mathrm{F}$ & ATAGTGCTGAAGGTACAACGGAGAA \\
\hline & & $\mathrm{R}$ & ССТССССGGCAGAGGAT \\
\hline New sequence matched to UniGene Bt.33 875 & AY999166 & $\mathrm{F}$ & TCTATGGCATTCCAGCGGATAT \\
\hline & & $\mathrm{R}$ & GTCTTTTTATTTAACATAAGGCCAAACAAG \\
\hline
\end{tabular}

${ }^{*} \mathrm{~F}$, forward primer; $\mathrm{R}$, reverse primer; $\mathrm{P}$, probe. 
Reagent; Ambion Europe Ltd, Huntingdon, UK). The TaqMan method (O'Shaughnessy et al. 2002) was used for three transcripts encoding aromatase (CYP19A1), inhibin $\alpha$-subunit (INHA) and glia-derived nexin (SERPINE2), while SYBR Green (SYBR Green JumpStart Taq ReadyMix; Sigma-Aldrich Company Ltd) was used for the remaining transcripts (Evans et al. 2004, Mihm et al. 2006). All primers and probes (only for the TaqMan PCR protocol) were designed using Primer Express Software v2.0.0 (Applied Biosystems), synthesised by MWG Biotech AG (Ebersberg, Germany) and used in concentrations of $200 \mu \mathrm{M}$. Reactions were carried out in the Stratagene Thermocycler Mx3000P (Stratagene Europe, Amsterdam, The Netherlands), and the Stratagene algorithm was used to estimate threshold cycle numbers $\left(C_{\mathrm{t}}\right)$. Primers and probes are listed in Table 3.

Four transcripts encoding ribosomal protein L2 (RPL2), ribosomal protein L36 (RPL36), acidic ribosomal phosphoprotein P0 (RPLPO) and actin, $\beta(A C T B)$ were tested to determine their suitability as endogenous reference genes in the real-time PCR study. Three of these transcripts (RPL2, RPL36 and RPLPO) proved to be unsuitable as reference genes, because the mRNA expression was too low and/or the target gene expression calculated relative to the reference was too variable between follicles from the same stages of development for statistical analysis. However, realtime PCR results using $A C T B$ as the endogenous reference gene were consistent between follicles from the same stages of development and with other molecular studies of DF development (Evans et al. 2004, Fayad et al. 2004, Mihm et al. 2006). Thus, ACTB was used as the endogenous reference in the real-time PCR study, although it may underestimate transcripts upregulated in the DF (Neuvians et al. 2005). Expression levels relative to $A C T B$ were calculated using $2^{-\Delta C_{t}}$.

\section{Analysis of SAGE data and statistical analyses}

Differences in tag frequency between the SAGE libraries were analysed using the $\chi^{2}$ test (Man et al. 2000). This study aimed to identify transcripts differentially regulated in the DF as it transits from the $\mathrm{FSH}$ - to the $\mathrm{LH}$-dependent development stage. Consequently, an initial comparison was made between the DF and $\mathrm{COH}$ libraries that identified 597 differentially expressed tags $(P \leq 0.05)$. Expression of these tags was then compared between the DF and SF SAGE libraries, and 93 tags were identified, which were significantly different $(P \leq 0.05)$ between the DF and both the $\mathrm{COH}$ and SF libraries (Table 2). The SAGEmap facility was then used to match differentially expressed SAGE tags to bovine UniGene clusters (http://www.ncbi.nlm.nih.gov/SAGE/) up to and through January 2007. When the tags are matched to more than one UniGene cluster, the cluster with the complete mRNA sequence and/or the majority of sequences containing the tag is presented. The SAGE technique also generates a slightly longer sequence for many tags (15 nucleotides), and this longer sequence was used to map the tag TTGATGTTTG to one UniGene cluster. Bovine (Bt.) UniGene cluster numbers can be accessed at http://www.ncbi.nlm.nih.gov/SAGE/, and full gene descriptions can be accessed at http://www.genenames.org/cgibin/hgnc_search.pl.
Differentially expressed SAGE tags matched to UniGene clusters also underwent gene ontology analysis based on the GO biological process (www.geneontology.org) regulated by the encoded gene. $\chi^{2}$ analysis was again used to determine whether the number of encoded proteins regulating tissue development, DNA/RNA synthesis, protein synthesis or unknown biological processes differed $(P \leq 0.05)$ between the transcripts expressed at the highest levels in the DF and the transcripts expressed at lower levels in the DF compared with the $\mathrm{COH}$ and/or SF libraries. Other differences $(P \leq 0.05)$ between the $\mathrm{COH}, \mathrm{DF}$ and SF not related to the SAGE libraries were analysed using one-way ANOVA or a paired t-test (only for DF versus SF comparisons). Steroid concentrations and relative gene expression values were log transformed to pass normality tests if indicated, but untransformed data are presented (mean \pm S.E.M).

\section{Acknowledgements}

The authors would like to acknowledge staff at Cochno Farm, University of Glasgow, for animal care and maintenance. This study was funded by BBSRC $36727 / 1$ to MM and PO'S. The authors declare that there is no conflict of interest that would prejudice the impartiality of this scientific work.

\section{References}

Adams GP, Kot K, Smith CA \& Ginther OJ 1993 Selection of a dominant follicle and suppression of follicular growth in heifers. Animal Reproduction Science 30 259-271.

Aloi JA, Dalkin AC, Schwartz NB, Yasin M, Mann B, Haisenleder DJ \& Marshall JC 1995 Ovarian inhibin subunit gene-expression - regulation by gonadotropins and estradiol. Endocrinology 136 1227-1232.

Angelastro JM, Torocsik B \& Greene LA 2002 Nerve growth factor selectively regulates expression of transcripts encoding ribosomal proteins. BMC Neuroscience 33.

Austin EJ, Mihm M, Evans ACO, Knight PG, Ireland JLH, Ireland JJ \& Roche JF 2001 Alterations in intrafollicular regulatory factors and apoptosis during selection of follicles in the first follicular wave of the bovine oestrous cycle. Biology of Reproduction 64 839-848.

Babu PS, Krishnamurthy H, Chedrese PJ \& Sairam MR 2000 Activation of extracellular-regulated kinase pathways in ovarian granulosa cells by the novel growth factor type 1 follicle-stimulating hormone receptor. Journal of Biological Chemistry 275 27615-27626.

Baerwald AR, Adams GP \& Pierson RA 2003 Characterization of ovarian follicular wave dynamics in women. Biology of Reproduction 69 1023-1031.

Bao B \& Garverick HA 1998 Expression of steroidogenic enzyme and gonadotropin receptor genes in bovine follicles during ovarian follicular waves: a review. Journal of Animal Science 76 1903-1921.

Bao B, Garverick HA, Smith GW, Smith MF, Salfen BE \& Youngquist RS 1997 Changes in messenger ribonucleic acid encoding luteinizing hormone receptor, cytochrome $\mathrm{P} 450$-side chain cleavage, and aromatase are associated with recruitment and selection of bovine ovarian follicles. Biology of Reproduction 56 1158-1168.

Beg MA, Bergfelt DR, Kot K \& Ginther OJ 2002 Follicle selection in cattle: dynamics of follicular fluid factors during development of follicle dominance. Biology of Reproduction 66 120-126.

Camors E, Monceau V \& Charlemagne D 2005 Annexins and $\mathrm{Ca}^{2+}$ handling in the heart. Cardiovascular Research 65 793-802.

Canty MJ, Boland MP, Evans AC \& Crowe MA 2006 Alterations in follicular IGFBP mRNA expression and follicular fluid IGFBP concentrations during the first follicle wave in beef heifers. Animal Reproduction Science 93 199-217. 
Carnegie JA \& Tsang BK 1984 The calcium-calmodulin system: participation in the regulation of steroidogenesis at different stages of granulosa cell differentiation. Biology of Reproduction 30 515-522.

Chen JJ, Rowley JD \& Wang SM 2000 Generation of longer cDNA fragments from serial analysis of gene expression tags for gene identification. PNAS 97 349-353.

Chiang Y, Schneiderman MH \& Vishwanatha JK 1993 Annexin II expression is regulated during mammalian cell cycle. Cancer Research $\mathbf{5 3}$ 6017-6021.

Coutts AS \& La Thangue N 2006 The p53 response during DNA damage: impact of transcriptional cofactors. Biochemical Society Symposium 73 181-189.

Evans ACO \& Fortune JE 1997 Selection of the dominant follicle in cattle occurs in the absence of differences in the expression of messenger ribonucleic acid for gonadotropin receptors. Endocrinology $\mathbf{1 3 8}$ 2963-2971.

Evans ACO, Ireland JLH, Winn ME, Lonergan P, Smith GW, Coussens PM \& Ireland JJ 2004 Identification of genes involved in apoptosis and dominant follicle development during follicular waves in cattle. Biology of Reproduction 70 1475-1484.

Evers JLH 2002 Female subfertility. Lancet 360 151-159.

Fayad T, Levesque V, Sirois J, Silversides DW \& Lussier JG 2004 Gene expression profiling of differentially expressed genes in granulosa cells of bovine dominant follicles using suppression subtractive hybridization. Biology of Reproduction 70 523-533.

Filion F, Bouchard N, Goff AK, Lussier JG \& Sirois J 2001 Molecular cloning and induction of bovine prostaglandin $\mathrm{E}$ synthase by gonadotropins in ovarian follicles prior to ovulation in vivo. Journal of Biological Chemistry 276 34323-34330.

Ginther OJ, Kot K, Kulick LJ \& Wiltbank MC 1997 Emergence and deviation of follicles during the development of follicular waves in cattle. Theriogenology 48 75-87.

Ginther OJ, Beg MA, Donadeu FX \& Bergfelt DR 2003 Mechanism of follicle deviation in monovular farm species. Animal Reproduction Science 78 239-257.

Hennebold JD, Tanaka M, Saito J, Hanson BR \& Adashi EY 2000 Ovaryselective genes I: the generation and characterization of an ovaryselective complementary deoxyribonucleic acid library. Endocrinology 141 2725-2734.

Ireland JL \& Ireland J 1994 Changes in expression of inhibin/activin alpha, beta A and beta B subunit messenger ribonucleic acids following increases in size and during different stages of differentiation or atresia of non-ovulatory follicles in cows. Biology of Reproduction $\mathbf{5 0}$ 492-501.

Ireland JJ \& Roche JF 1983 Development of non-ovulatory antral follicles in heifers: changes in steroids in follicular fluid and receptors for gonadotropins. Endocrinology 112 150-156.

Kadakia R, Arraztoa JA, Bondy C \& Zhou J 2001 Granulosa cell proliferation is impaired in the Igf1 null ovary. Growth Hormone and IGF Research 11 220-224.

Kawate N \& Okuda K 1998 Coordinated expression of splice variants for luteinizing hormone receptor messenger RNA during the development of bovine corpora lutea. Molecular Reproduction and Development $\mathbf{5 1}$ 66-75.

Khanna N, Reddy VG, Tuteja N \& Singh N 2000 Differential gene expression in apoptosis: identification of ribosomal protein S29 as an apoptotic inducer. Biochemical and Biophysical Research Communications 277 476-486.

Landry D, Sullivan S, Nicolaides M, Redhead C, Edelman A, Field M, Al-Awqati Q \& Edwards J 1993 Molecular cloning and characterization of p64, a chloride channel protein from kidney microsomes. Journal of Biological Chemistry 268 14948-14955.

Levallet J, Mittre H, Delarue B \& Carreau S 1998 Alternative splicing events in the coding region of the cytochrome $\mathrm{P}$ aromatase gene in male rat germ cells. Journal of Molecular Endocrinology 20 305-312.

Lucy MC 2001 Reproductive loss in high-producing dairy cattle: where will it end? Journal of Dairy Science 84 1277-1293.

Ludwig A \& Tenhaken R 2001 Suppression of the ribosomal L2 gene reveals a novel mechanism for stress adaptation in soybean. Planta 212 792-798.

Man MZ, Wang X \& Wang Y 2000 POWER_SAGE: comparing statistical tests for SAGE experiments. Bioinformatics 16 953-959.
Matsuura T, Sugimura M, Iwaki T, Ohashi R, Kanayama N \& Nishihira J 2002 Anti-macrophage inhibitory factor antibody inhibits PMSG-hCGinduced follicular growth and ovulation in mice. Journal of Assisted Reproduction and Genetics 19 591-595.

McRae RS, Johnston HM, Mihm M \& O'Shaughnessy PJ 2005 Changes in mouse granulosa cell gene expression during early luteinization. Endocrinology 146 309-317.

Mihm M \& Bleach ECL 2003 Endocrine regulation of ovarian antral follicle development in cattle. Animal Reproduction Science $\mathbf{7 8}$ 217-237.

Mihm M, Good TEM, Ireland JLH, Ireland JJ, Knight PG \& Roche JF 1997 Decline in serum follicle-stimulating hormone concentrations alters key intrafollicular growth factors involved in selection of the dominant follicle in heifers. Biology of Reproduction $\mathbf{5 7}$ 1328-1337.

Mihm M, Austin EA, Good TEM, Ireland JLH, Knight PG, Roche JF \& Ireland JJ 2000 Identification of potential intrafollicular factors involved in selection of dominant follicles in heifers. Biology of Reproduction $\mathbf{6 3}$ 811-819.

Mihm M, Baker PJ, Ireland JLH, Smith GW, Coussens PM, Evans ACO \& Ireland JJ 2006 Molecular evidence that growth of dominant follicles involves a reduction in follicle stimulating hormone - dependence and an increase in luteinizing hormone - dependence in cattle. Biology of Reproduction 74 1051-1059.

Mitchell RA \& Bucala R 2000 Tumor growth-promoting properties of macrophage migration inhibitory factor (MIF). Seminars in Cancer Biology 10 359-366.

Neuvians TP, Gashaw I, Sauer CG, von Ostau C, Kliesch S, Bergmann M, Hacker A \& Grobholz R 2005 Standardization strategy for quantitative $\mathrm{PCR}$ in human seminoma and normal testis. Journal of Biotechnology 117 163-171.

Nguyen MT, Lue $H$, Kleemann R, Thiele M, Tolle G, Finkelmeier D, Wagner E, Braun A \& Bernhagen J 2003 The cytokine macrophage migration inhibitory factor reduces pro-oxidative stress-induced apoptosis. Journal of Immunology $1703337-3347$.

O'Shaughnessy PJ, Willerton L \& Baker PJ 2002 Changes in Leydig cell gene expression during development in the mouse. Biology of Reproduction 66 966-975.

O'Shaughnessy PJ, Fleming L, Baker PJ, Jackson G \& Johnston H 2003 Identification of developmentally regulated genes in the somatic cells of the mouse testis using serial analysis of gene expression. Biology of Reproduction 69 797-808.

Rajapaksha WR, Robertson L \& O'Shaughnessy PJ 1996 Expression of follicle-stimulating hormone-receptor mRNA alternate transcripts in bovine granulosa cells during luteinization in vivo and in vitro. Molecular and Cellular Endocrinology 120 25-30.

Robker RL \& Richards JS 1998 Hormone-induced proliferation and differentiation of granulosa cells: a coordinated balance of the cell cycle regulators cyclin D2 and p27(Kip1). Molecular Endocrinology 12 924-940.

Roche JF, Mihm M, Diskin M \& Ireland JJ 1998 A review of regulation of follicle growth in cattle. Journal of Animal Science 76 (Suppl 3) 16-29.

van Santbrink EJ, Hop WC, van Dessel TJ, de Jong FH \& Fauser BC 1995 Decremental follicle-stimulating hormone and dominant follicle development during the normal menstrual cycle. Fertility and Sterility $6437-43$.

Screaton GR, Caceres JF, Mayeda A, Bell MV, Plebanski M, Jackson DG, Bell JI \& Krainer AR 1995 Identification and characterization of three members of the human SR family of pre-mRNA splicing factors. EMBO Journal 14 4336-4349.

Sheikh MS, Hollander MC \& Fornance AJ Jr 2000 Role of GADD45 in apoptosis. Biochemical Pharmacology 59 43-45.

Shires J, Theodoridis E \& Hayday AC 2001 Biological insights into TCR $\gamma \delta+$ and TCR $\alpha \beta+$ intraepithelial lymphocytes provided by serial analysis of gene expression (SAGE). Immunity 15 419-434.

Sisco B, Hagemann LJ, Shelling AN \& Pfeffer PL 2003 Isolation of genes differentially expressed in dominant and subordinate bovine follicles. Endocrinology 144 3904-3913.

De Smaele E, Zazzeroni F, Papa S, Nguyen DU, Jin R, Jones J, Cong R \& Franzoso G 2001 Induction of gadd45beta by NF- $\kappa B$ downregulates proapoptotic JNK signaling. Nature 414 308-313. 
Stanton JL, Macgregor AB \& Green DPL 2002 Using expressed sequence tag databases to identify ovarian genes of interest. Molecular and Cellular Endocrinology 191 11-14.

Stocco CO, Lau LF \& Gibori G 2002 A calcium/calmodulin-dependent activation of ERK1/2 mediates JunD phosphorylation and induction of nur77 and 20alpha-hsd genes by prostaglandin F2alpha in ovarian cells. Journal of Biological Chemistry 277 3293-3302.

Sunderland SJ, Crowe MA, Boland MP, Roche JF \& Ireland JJ 1994 Selection, dominance and atresia of follicles during the oestrous cycle of heifers. Journal of Reproduction and Fertility 101 547-555.

Tanaka M, Hennebold JD, Miyakoshi K, Teranishi T, Ueno K \& Adashi EY 2003 The generation and characterization of an ovary-selective cDNA library. Molecular and Cellular Endocrinology 202 67-69.

Velculescu VE, Zhang L, Vogelstein B \& Kinzler KW 1995 Serial analysis of gene expression. Science $\mathbf{2 7 0}$ 484-487.
Yuan W, Bao B, Garverick HA, Youngquist RS \& Lucy MC 1998 Follicular dominance in cattle is associated with divergent patterns of ovarian gene expression for insulin-like growth factor (IGF)-I, IGF-II, and IGF binding protein-2 in dominant and subordinate follicles. Domestic Animal Endocrinology 15 55-63.

Received 9 September 2006

First decision 9 November 2006

Revised manuscript received 3 October 2007

Accepted 30 October 2007 